\title{
Resveratrol down-regulates the growth and telomerase activity of breast cancer cells in vitro
}

\author{
GIULIA LANZILLI $^{1 *}$, MARIA PIA FUGGETTA ${ }^{1 *}$, MARIA TRICARICO $^{1}$, ANDREA COTTARELLI $^{1}$, \\ ANNALUCIA SERAFINO ${ }^{1}$, ROBERTO FALCHETTI ${ }^{1}$, GIAMPIETRO RAVAGNAN ${ }^{2}$, \\ MARIO TURRIZIANI ${ }^{3}$, RICCARDO ADAMO ${ }^{4}$, ORNELLA FRANZESE ${ }^{4}$ and ENZO BONMASSAR ${ }^{1}$
}

\begin{abstract}
${ }^{1}$ Institute of Neurobiology and Molecular Medicine, National Research Council - CNR, Area Ricerca Roma 'Tor Vergata', Via Fosso del Cavaliere 100, I-00133 Rome; ${ }^{2}$ Department of Environmental Science, Cà Foscari, University of Venice, Venice; ${ }^{3}$ Department of Internal Medicine, University of Tor Vergata, Via Montpellier 1; ${ }^{4}$ Department of Neuroscience, University of Tor Vergata, Via Montpellier 1, I-00133 Rome, Italy
\end{abstract}

Received September 19, 2005; Accepted November 11, 2005

\begin{abstract}
A number of previous studies investigated the in vitro effects of resveratrol on malignant human breast epithelial cell replication. The aim of the present study was to evaluate the activity of resveratrol on human metastatic breast cancer cells. The study was performed on the MCF-7 tumor cell line. Cell growth, cell cycle perturbation and apoptosis were evaluated by trypan blue dye exclusion assay, flow cytometric analysis and confocal fluorescence microscopy. TRAP assay and Western blot analysis respectively detected levels of telomerase activity and levels of hTERT in intracellular compartments of MCF-7 cells treated with resveratrol. Resveratrol has a direct inhibitory effect on cell proliferation. The results demonstrate that the drug induces apoptosis in MCF-7 cells, in a time- and concentrationrelated manner. Our results also show that the growth-inhibitory effect of resveratrol on malignant cells is mainly due to its ability to induce S-phase arrest and apoptosis in association with reduced levels of telomerase activity. In particular, TRAP assay and Western blot analysis respectively showed that resveratrol treatment down-regulates the telomerase activity of target cells and the nuclear levels of hTERT, the reverse
\end{abstract}

Correspondence to: Dr Giulia Lanzilli, Institute of Neurobiology and Molecular Medicine, CNR, Area Ricerca Roma 'Tor Vergata', Via Fosso del Cavaliere 100, I-00133 Rome, Italy

E-mail: Giulia.Lanzilli@artov.inmm.cnr.it

${ }^{*}$ Contributed equally

Abbreviations: TLMA, telomerase activity; hTERT, human telomerase reverse transcriptase; DMSO, dimethyl sulfoxide; FCS, fetal calf serum; CM, complete medium; PI, propidium iodide; CLSM, confocal laser scanning microscopy

Key words: resveratrol, antiproliferative, MCF-7, apoptosis, telomerase transcriptase subunit of the telomerase complex. In our experimental model of breast cancer, resveratrol shows direct antiproliferative and pro-apoptotic effects. Studies on telomerase function and intracellular hTERT distribution point out that this agent is endowed with additional suppressive functions on critical tumor biological properties. These results speak in favor of a potential role of resveratrol in chemoprevention/chemotherapy of breast cancer.

\section{Introduction}

The trans-isomer of resveratrol (3,5,4'-trihydroxystilbene) is a natural phytoalexin present in a limited number of Spermatophyta; in particular, in grapes, fruit and root extracts, where it is synthesized in response to stress conditions $(1,2)$. This molecule was reported to exhibit a wide range of biological and pharmacological activities both in vitro and in vivo (3). Indirect evidence suggests that the presence of resveratrol in red wine may explain for the reduced risk of coronary heart disease associated with moderate wine consumption (4-10). This effect has been attributed to the inhibition of platelet aggregation and coagulation, in addition to the antioxidant and anti-inflammatory activity of resveratrol $(11,12)$. Resveratrol was found to have antioxidant properties (12), to inhibit platelet aggregation $(10,13)$ and oxidation of low-density lipoproteins (11), to promote the production of nitric oxide by vascular endothelium (14) and to inhibit NF- $\kappa \mathrm{B}$ activity (15-19). Moreover, resveratrol inhibits either cyclooxygenase-1 (20) and cyclooxygenase-2 (21), downregulates prostaglandin biosynthesis $(20,22)$ and suppresses carrageenan-induced paw edema (20). In addition, this compound exerts a potent chemopreventive effect in several carcinogenesis models (20). Resveratrol is capable of inhibiting cellular processes associated with the three major stages of carcinogenesis, tumor initiation, promotion and progression $(20,23-25)$. In a wide variety of tumor cell lines, resveratrol has been shown to exhibit anti-cancer properties related to its ability to induce a significant suppression of cell proliferation, to cause cell-cycle arrest and to trigger apoptosis $(15,20,23-38)$. 
A number of studies have investigated the in vitro effects of resveratrol on malignant human breast epithelial cell lines (15,29-38). Previous results indicated that treatment with resveratrol has a direct antiproliferative and pro-apoptotic effect on these cells and suggested that this activity could be mediated by at least 4 different mechanisms: a) antioxidant effects (22), b) inhibiting activity on cyclooxygenase-2 (21), c) interaction with estrogen receptors (16,31,32,35-38), and d) effects on proliferation and cell cycle through modulation of different cell signaling pathways $(16,25,29,33,34,38,39)$. However, these effects cannot fully explain the underlying molecular mechanisms for the anti-cancer activity of resveratrol.

Telomerase is an RNA-dependent DNA polymerase with reverse transcriptase activity that adds hexameric repetitive sequences (TTAGGG) to chromosome ends in dividing cells (40) to ensure chromosomal stability and prevent ageing (41). Regulation of telomerase activity (TLMA) in human cells plays a significant role in the development of cancer (42-45). High TLMA was found to be associated with cancer cells and not with differentiated cells or homologous normal tissue (46). In normal cells, in the absence of TLMA, telomeric sequences progressively shorten during cell division, until cells stop proliferating (47). Most tumor cells, with indefinite proliferative ability, maintain telomeres through the expression of TLMA, which is always associated with the expression of the catalytic subunit of the enzyme, the human telomerase reverse transcriptase (hTERT). A strong correlation has been observed between hTERT mRNA expression and TLMA in a variety of epithelial cancers, including breast cancer (48). Telomerase has been frequently described as an ideal cancer target because it is activated in most malignant cells (42-44). Inhibition of hTERT results in telomere loss and limits the growth of tumor cells that undergo apoptosis when their telomeres reach a critically short length. On the other hand, TLMA can be also regulated by post-translational modifications of the enzyme. In particular, telomerase function is conditioned by phosphorylation and translocation of hTERT from the cytoplasm to the nuclear compartment, where the enzyme is required to promote telomere elongation. In addition, Protein kinase B, also known as Akt, has been shown to phosphorylate and functionally activate hTERT $(38,49)$. Although the mechanism of nuclear translocation of hTERT has not been fully elucidated, data from the literature demonstrate that NF- $\mathrm{KB}$ plays an important role in regulating TLMA by modulating the nuclear translocation of hTERT (49).

The present work illustrates the effects of resveratrol treatment on apoptosis, cell cycle kinetics and TLMA of MCF-7, a metastatic human breast cancer cell line. Our results show that the growth-inhibitory effect of resveratrol on MCF-7 cells is mainly due to its ability to induce S-phase arrest and apoptosis in a concentration-related manner. This finding was confirmed by flow cytometry and confocal fluorescent microscopy. Moreover, we found that resveratrol is able to downregulate TLMA. Western blot analysis of nuclear and cytoplasmic compartments showed that resveratrol was able to reduce the nuclear expression of hTERT protein. Moreover, the agent was found to be able to up-regulate the cytoplasmic fraction, probably through an alteration of cellular localization of the catalytic subunit.

\section{Materials and methods}

Resveratrol. Trans-resveratrol (3,5,4'-trihydroxy-trans-stilbene Sigma Chemical Co., St Louis, MO) was dissolved in dimethyl sulfoxide (DMSO) at a concentration of $200 \mathrm{mM}$, stored as stock solution at $-80^{\circ} \mathrm{C}$, and diluted in culture medium just prior to use.

Cell culture. The human breast epithelial cell line (estrogen receptor positive), $\mathrm{MCF}-7$, derived from a metastatic carcinoma, was cultured at $37^{\circ} \mathrm{C}$ in a $5 \% \mathrm{CO}_{2}$ humidified atmosphere and maintained in RPMI-1640 (Hyclone Europe, Cramlington, UK) supplemented with $10 \%$ heat-inactivated $\left(56^{\circ} \mathrm{C}, 30 \mathrm{~min}\right)$ fetal calf serum (FCS- Hyclone Laboratories, Logan, UK), $2 \mathrm{mM}$ L-glutamine (Glu) and antibiotics (Life Technologies Ltd., Paisley, Scotland), herein referred to as complete medium (CM).

Cell treatment. Fully confluent cells were harvested, counted, suspended in CM and seeded into 24-well tissue culture plates (Falcon) in $2 \mathrm{ml} /$ well at a concentration of $1 \times 10^{5}$ cell/ $\mathrm{ml}$ and allowed to adhere overnight. MCF-7 cells in logarithmic growth phase were treated with graded amounts of resveratrol, dissolved in sterile DMSO and added to the well in $50 \mu \mathrm{l}$ of $\mathrm{CM}$. The plates were incubated at $37^{\circ} \mathrm{C}$ in a $5 \% \mathrm{CO}_{2}$ humidified atmosphere for 24,48 or $72 \mathrm{~h}$. Three replica wells were used for controls and each drug concentration. The final dilution (1:400) of DMSO in culture medium was the same for each tested concentration of resveratrol. As a control, cell cultures treated with DMSO 1:400 were used. At the end of incubation the cells were harvested by trypsinization.

Determination of cell growth and viability. Cells were seeded in 24-well tissue culture plates (Falcon) at a concentration of $5 \times 10^{4}$ cells $/ \mathrm{ml}$ and allowed to adhere overnight. Cells were incubated with resveratrol at final concentrations of 5, 10, 20 and $40 \mu \mathrm{g} / \mathrm{ml}$ (3 wells for each treatment) or DMSO alone as control. The plates were incubated at $37^{\circ} \mathrm{C}$ in a $5 \% \mathrm{CO}_{2}$ humidified atmosphere for 24,48 or $72 \mathrm{~h}$. Cell growth and viability were evaluated every $24 \mathrm{~h}$. Trypsinized cells were manually counted using a hemocytometer and cell viability was determined by trypan blue dye exclusion assay.

Flow cytometric analysis. For apoptosis and cell cycle analysis, both floating and adherent MCF-7 cells, detached by trypsinization, were washed in PBS and fixed with $50 \%$ aceton: methanol 1:4 in PBS at $4^{\circ} \mathrm{C}$ for at least $18 \mathrm{~h}$. After two washes in PBS, the cells were suspended $\left(1 \times 10^{6} / \mathrm{ml}\right)$ in PBS containing $50 \mu \mathrm{g} / \mathrm{ml}$ of propidium iodide (PI) and $100 \mathrm{KU} / \mathrm{ml}$ of RNase A and incubated in the dark at room temperature for $30 \mathrm{~min}$. The DNA content per cell was evaluated by PI fluorescence measured on a linear scale using a FACScan flow cytometer (Becton-Dickinson, San Jose, CA) with an argon ion laser emitting at $488 \mathrm{~nm}$. Data collection of 10,000 cells/sample was gated utilizing forward light scatter and side light scatter to exclude cell debris and aggregates. All data were recorded using CellQuest software (Becton-Dickinson). Cell cycle analysis was performed using ModFit LT software (BectonDickinson). Apoptotic cells were determined by their hypochromic, sub-G1 staining profiles (50). 
Confocal laser scanning microscopy (CLSM). Analysis of apoptosis-like morphological modifications was carried out on cells grown on coverslips fixed with $4 \%$ paraformaldehyde in PBS (pH 7.4) for $10 \mathrm{~min}$ at room temperature (RT). After washing in PBS, for nuclear labelling, samples were stained with $2 \mu \mathrm{g} / \mathrm{ml}$ PI and $0.1 \mathrm{mg} / \mathrm{ml}$ RNase for $5 \mathrm{~min}$ at RT. Coverslips were mounted on glass microscope slides, in the presence of glicerol/PBS at a ratio of $4: 1$ and observed on a LEICA TCS 4D confocal laser scanning microscope supplemented with an Argon/Kripton laser and equipped with $40 \times 1.00-0.5$ and $100 \times 1.3-0.6$ oil immersion lenses. The excitation and emission wavelengths employed were 488 and $590 \mathrm{~nm}$, respectively. The acquisitions were recorded, employing pseudo-color representation.

Evaluation of TLMA. Cells were seeded in 24-well tissue culture plates (Falcon) at a concentration of $5 \times 10^{4}$ cells $/ \mathrm{ml}$ and allowed to adhere overnight. Cells were incubated with resveratrol at final concentrations of 5, 10, 20 and $40 \mu \mathrm{g} / \mathrm{ml}$ (3 wells for each treatment) or DMSO alone as control. The plates were incubated at $37^{\circ} \mathrm{C}$ in a $5 \% \mathrm{CO}_{2}$ humidified atmosphere. After 24 and $48 \mathrm{~h}$ of incubation, the cells were harvested, counted and processed for 'telomerase repeat amplification protocol' (TRAP) assay, as previously described (51). This method is based on the PCR amplification of telomerase extension products. Briefly, a volume of control culture containing $1 \times 10^{5}$ viable cells was transferred into $2-\mathrm{ml}$ eppendorf vials. After centrifugation at $4^{\circ} \mathrm{C}$ for $10 \mathrm{~min}$, followed by careful removal of the supernatant, all pellets were lysed with $200 \mu 1$ of ice-cold extraction buffer containing $0.1 \%$ NP-40, 10 mM Tris- $\mathrm{HCl}, \mathrm{pH} 7.5,1 \mathrm{mM} \mathrm{MgCl} 2,1 \mathrm{mM}$ EGTA, $0.25 \mathrm{mM}$ sodium deoxycholate, $150 \mathrm{mM} \mathrm{NaCl}$, $10 \%$ glycerol, $5 \mathrm{mM}$ 3-mercaptoethanol and $0.1 \mathrm{mM}$ [4-(2aminoethyl)-benzene-sulfonyl fluoride hydrochloride]. After $30 \mathrm{~min}$ of incubation on ice, samples were centrifuged at $16,000 \mathrm{rpm}$ for $20 \mathrm{~min}$. Supernatant lysates $(4 \mu 1)$ corresponding to $2 \times 10^{3}$ cells in a final volume of $50 \mu 1$ of reaction mixture were used for TRAP assay. The reaction mixture for TRAP assay contained $20 \mathrm{mM}$ Tris-HCL pH 8.3, $68 \mathrm{mM}$ $\mathrm{KCl}, 1.5 \mathrm{mM} \mathrm{MgCl}_{2}, 1 \mathrm{mM}$ EGTA, $0.05 \%$ Tween-20, $0.1 \mu \mathrm{g}$ of TS (5'-AATCCGTCGAGCAGAGTT) primer, $0.5 \mu \mathrm{M}$ T4 gene 32 protein, $50 \mu \mathrm{M}$ of each deoxynucleotide triphosphate. Samples were incubated at room temperature for $15 \mathrm{~min}$ to allow telomerase to extend TS primer. The reaction was stopped in ice and 2 units of TaqDNA polymerase, $2 \mu \mathrm{Ci}$ of [ $\left.\alpha-{ }^{32} \mathrm{P}\right] \mathrm{dCTP}(3,000 \mathrm{Ci} / \mathrm{mmol}$; Dupont NEN Research Products, Boston, MA, USA) and $0.1 \mu \mathrm{g}$ of CX oligonucleotide 5'-GTGCCCTTACCCTTACCCTTACCCTTA were added to each PCR tube. Amplification of telomeric products was performed by PCR (Perkin-Elmer Cetus, Norwalk, CT, USA) ( $94^{\circ} \mathrm{C}$ for $30 \mathrm{sec}, 50^{\circ} \mathrm{C}$ for $30 \mathrm{sec}, 72^{\circ} \mathrm{C}$ for $\left.1 \mathrm{~min} ; 31 \mathrm{cycles}\right)$. Reagents for TRAP assay were purchased from Boehringer Mannheim (Indianapolis, IN, USA) and oligonucleotide primers from Biogen (Rome, Italy). Analysis of $40 \mu 1$ of the PCR products was performed on $10 \%$ non-denaturing acrylamide gels. Gels were fixed in $0.5 \mathrm{M} \mathrm{NaCl}, 50 \%$ ethanol, $40 \mathrm{mM}$ sodium acetate $(\mathrm{pH} 4.2)$ and then exposed overnight to X-ray film (Kodak, Rochester, NY, USA) at $-80^{\circ} \mathrm{C}$.

Bidimensional densitometry of the 6-base repetitive ladder bands was performed using BioRad (Richmond, CA, USA) scanning apparatus (Imaging densitometer, GS-670; Molecular Analyst software). The signal intensity of each band was measured and corrected for the background. The sum of the adjusted signals, expressed in optical density per $\mathrm{mm}^{3}$ (OD/ $\mathrm{mm}^{3}$ ) of the ladder products in each lane, was used for semiquantitative analysis.

Western blot analysis. Western blot was performed separately on cytoplasmic and nuclear extracts, obtained according to the technique described by Andrews and Faller (52). The quality of nuclear and cytoplasmic preparations utilized in this study has been tested in order to rule out the contamination of cytoplasmic extract with nuclear material. Therefore, experiments have been performed using an mAb able to recognize histone $\mathrm{H} 1$. The results of these preliminary experiments show that nuclear, but not cytoplasmic, extract from MCF-7 cells was positive for the presence of $\mathrm{H} 1$ histone, as evidenced by Western blot analysis (data not shown).

Extracts obtained from $1 \times 10^{6}$ cells were separated by $10 \%$ SDS-PAGE, transferred to nitrocellulose membranes (BioRad), probed with anti-hTERT polyclonal antibody (Santa Cruz Biotechnology, Santa Cruz, CA) at 1:500 dilution, and detected using the ECL Plus Western detection kit (Amersham Pharmacia Biotech, Piscataway, NJ).

Statistical analysis. Results are means \pm SE. Statistical significance was determined using the Student's t-test.

\section{Results}

Antiproliferative effect of resveratrol. To investigate the ability of resveratrol to control the growth of MCF-7 breast cancer cells, various concentrations of resveratrol were added to MCF-7 cultures for 24, 48 and $72 \mathrm{~h}$. Fig. 1A shows the kinetics of tumor cell viability after exposure to the agent. In particular, at the concentration of $40 \mu \mathrm{g} / \mathrm{ml}$ the drug showed a potent cytotoxic effect; according to dye exclusion assay, $>90 \%$ of treated tumor cells were found dead on days 1-3 after treatment (Fig. 1A). Moreover, exposure of MCF-7 cells to 5,10 or $20 \mu \mathrm{g} / \mathrm{ml}$ resveratrol induced a statistically significant concentration-related increase in the percentage of dead cells that remained essentially constant for up to $72 \mathrm{~h}$.

Fig. 1B shows the effect of resveratrol on MCF-7 cell growth evaluated in terms of number of viable cells per culture. The results show that the growth kinetics of cells exposed to $5 \mu \mathrm{g} / \mathrm{ml}$ was similar to that of control cells. However, treatment with 10 or $20 \mu \mathrm{g} / \mathrm{ml}$ significantly reduced the exponential growth of tumor cells. This effect was significant as early as $24 \mathrm{~h}$ after treatment, and was maintained for at least $72 \mathrm{~h}$. At the concentration of $40 \mu \mathrm{g} / \mathrm{ml}$, resveratrol produced a dramatic drop in the number of MCF-7 cells after $24 \mathrm{~h}$, thus confirming its cytotoxic effect at this concentration when tumor cell viability was investigated (Fig. 1A).

Apoptotic effects of resveratrol. MCF-7 cells were treated with resveratrol at concentrations of $5,10,20$ or $40 \mu \mathrm{g} / \mathrm{ml}$ for 24,48 and $72 \mathrm{~h}$ and then the percentage of apoptotic cells was evaluated by flow cytometry. Apoptotic cells are represented by a broad hypodiploid peak (cells with a fractional DNA content), which is easily distinguishable from the narrow peak 
A
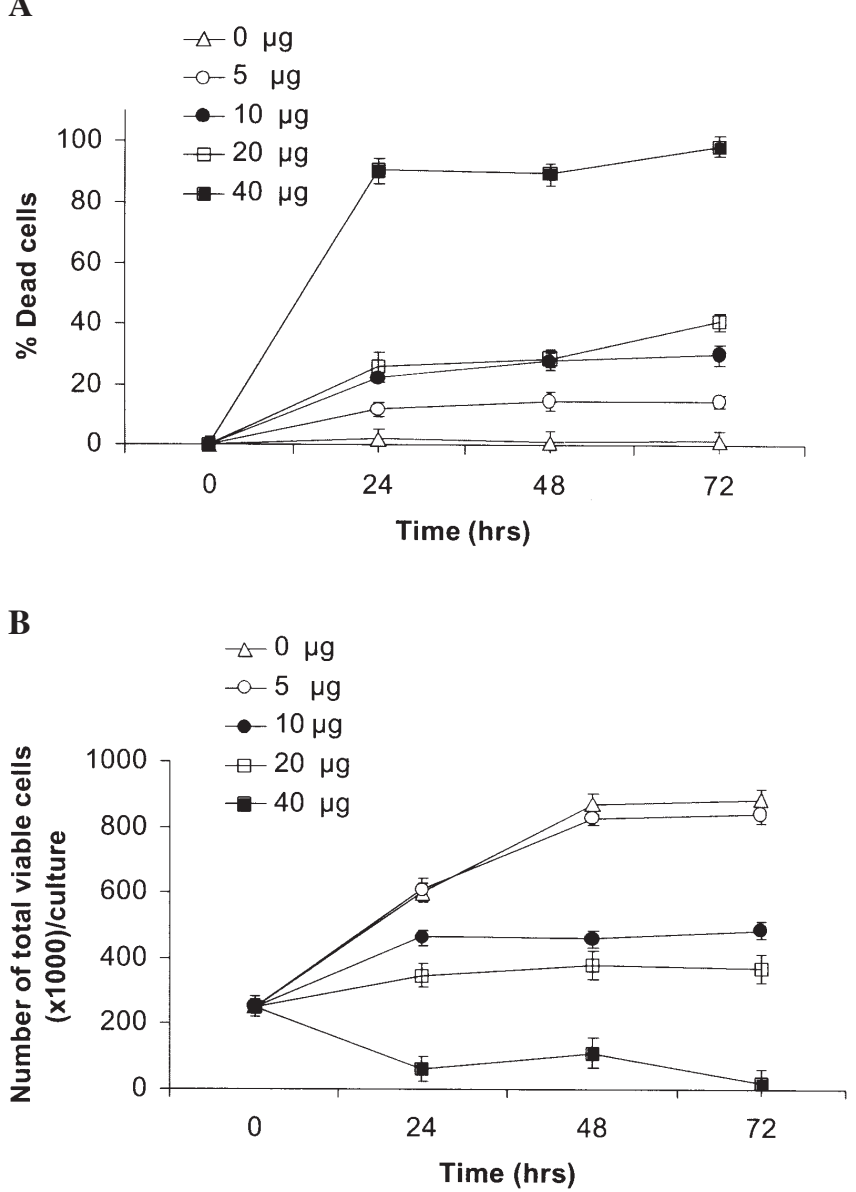

Figure 1. Effect of resveratrol on tumor cell viability (A) and cell growth kinetics (B). MCF-7 human breast cancer cells were cultured in CM or CM containing the indicated concentrations of resveratrol for 24,48 and $72 \mathrm{~h}$. Control groups were treated with DMSO alone. Tumor cell viability and cell growth were determined by trypan blue dye exclusion assay and cell count, respectively. Data on cell growth inhibition are expressed in terms of percentages with respect to control. All measurements were performed in duplicate, using three different cultures. Values represent the mean $\pm \mathrm{SE}$ of three wells from at least three independent experiments.

of cells with diploid DNA content in the red fluorescence channel (50). The fraction of apoptotic cells was therefore calculated by integrating the pre-G1 peak. This fraction is representative of cells with decreased staining for PI as an indicator for DNA fragmentation associated with apoptotic cell death. The results illustrated in Fig. 2 show that resveratrol induced apoptosis of MCF-7 cells in a concentration-dependent fashion. In particular, treatment with resveratrol at 10, 20 or $40 \mu \mathrm{g} / \mathrm{ml}$ for 24 or $48 \mathrm{~h}$ induced a significant increase in the frequency of cells with nucleosomal DNA fragmentation. At the concentration of $5 \mu \mathrm{g} / \mathrm{ml}$, resveratrol induced a slight but significant increase in apoptosis exclusively after $48 \mathrm{~h}$ of treatment. However, a decrease in the frequency of apoptosis was detected at $72 \mathrm{~h}$, as shown in Fig. 2. At this time-point, the percentages of apoptotic cells returned to values not statistically different from those of control cells.

To confirm the results obtained by flow cytometry, the induction of apoptotic cell death by resveratrol was evaluated by confocal fluorescence microscopy. MCF-7 tumor cells were treated with the compound ranging from 5 to $20 \mu \mathrm{g} / \mathrm{ml}$

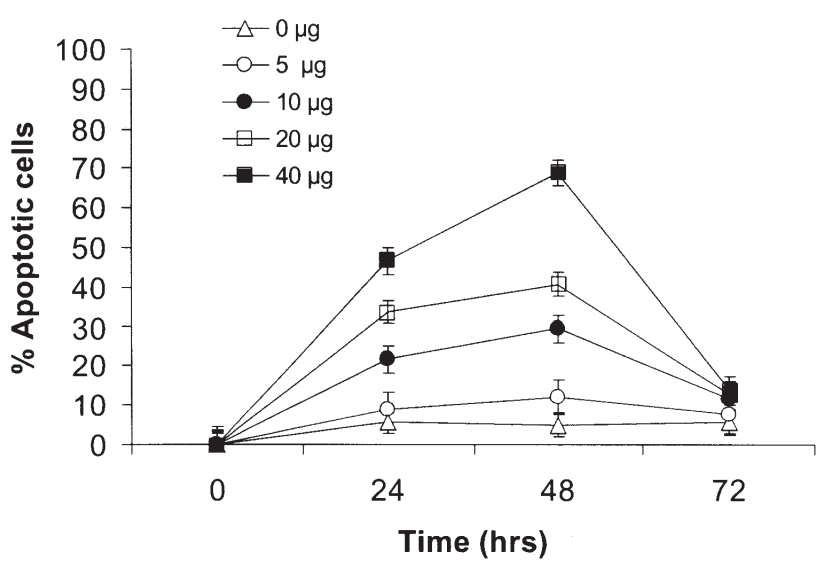

Figure 2. Effect of resveratrol on induction of apoptosis in MCF-7 human breast cancer cells. Cells were cultured in CM or CM containing the indicated concentrations of resveratrol for 24,48 and $72 \mathrm{~h}$. Control groups were treated with DMSO alone. At the end of the culture period, the cells were harvested and the percentages of apoptotic cells were evaluated by flow cytometry as described in Materials and methods. Values represent the mean $\pm \mathrm{SE}$ of three wells from at least three independent experiments.
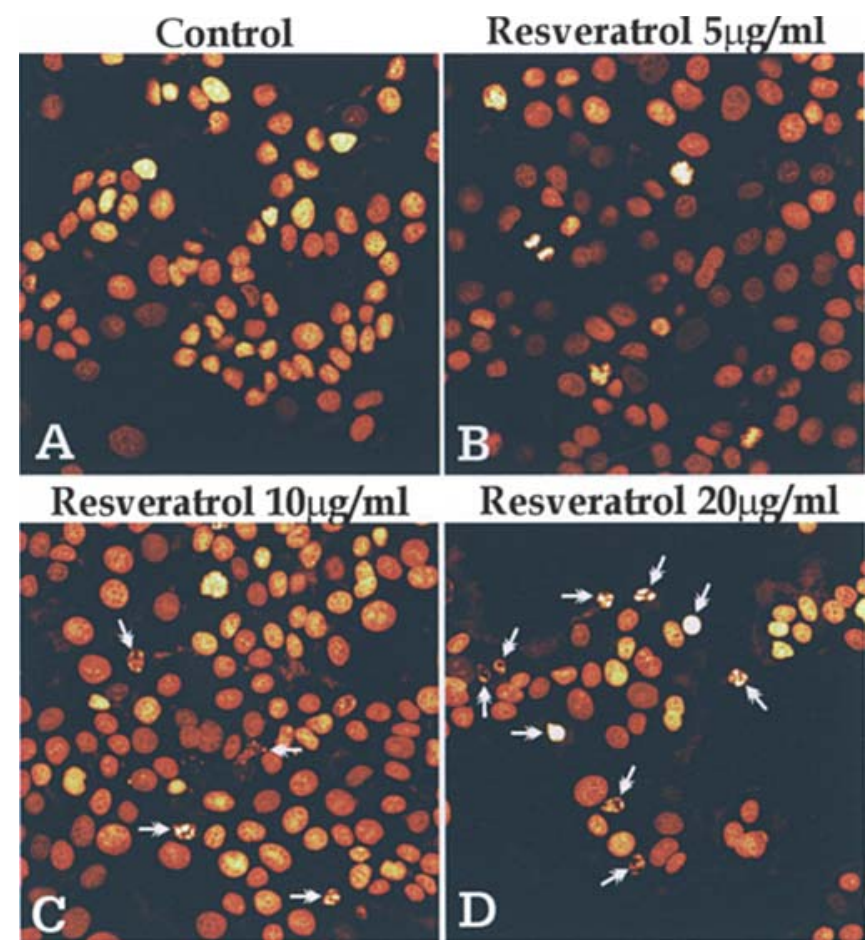

Figure 3. Effect of resveratrol on induction of apoptosis in MCF-7 cells evaluated by confocal fluorescence microscopy. Cells were exposed to DMSO (A), and 5 (B), 10 (C) and 20 (D) $\mu \mathrm{g} / \mathrm{ml}$ of resveratrol for $48 \mathrm{~h}$ and then stained with PI. Arrows indicate apoptotic cells with characteristic chromatin condensation and nuclear fragmentation in a representative experiment. Original magnification of confocal micrographs, $\mathrm{x} 40$.

for $48 \mathrm{~h}$. The induction of apoptotic cell death was accompanied by characteristic ultrastructural changes, such as chromatin condensation, nuclear fragmentation and collapse of the cell into membrane-bound apoptotic bodies. The results (Fig. 3) confirm that resveratrol, at a concentration of 10 (C) or 20 (D) $\mu \mathrm{g} / \mathrm{ml}$, increases the number of apoptotic cells as demonstrated by the presence of cells with characteristic 

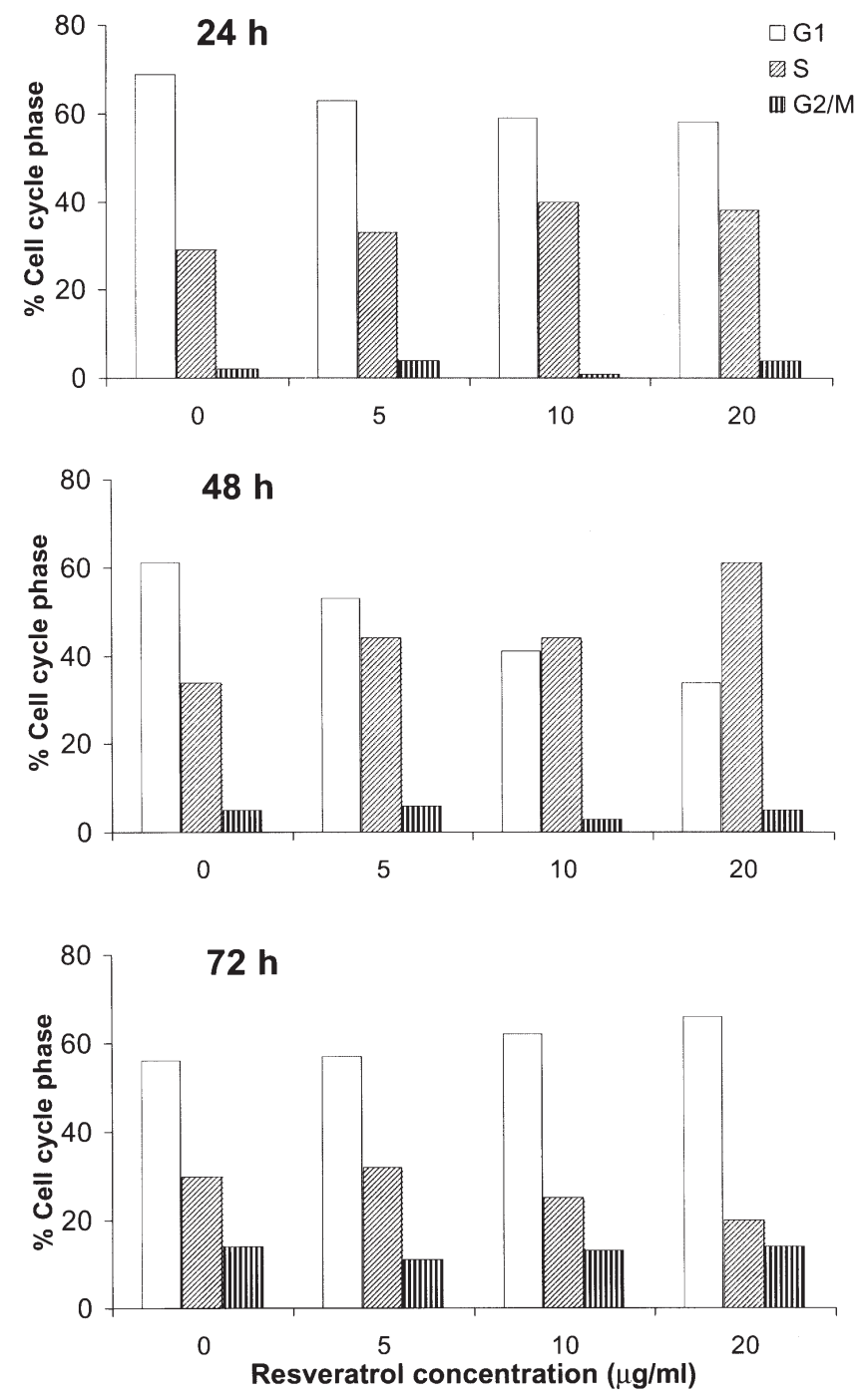

Figure 4. Effect of resveratrol on cell cycle phase distribution of MCF-7 human breast cancer cells. Cells were cultured in CM or CM containing the indicated concentrations of resveratrol for 24,48 and $72 \mathrm{~h}$, harvested, stained with PI and processed for flow cytometric analysis of DNA content. Control groups were treated with DMSO alone. Data are expressed in terms of mean \pm SE from triplicate determinations. Data are representative from at least three independent experiments.

fragmentation and condensation of nuclear chromatin (arrows). No apoptosis induction was observed for the lower concentration $(5 \mu \mathrm{g} / \mathrm{ml})$ of resveratrol (B) and for the untreated control (A). The original magnification of confocal micrographs was $\mathrm{x} 40$.

Effect of resveratrol on the cell cycle. To further investigate the mechanisms underlying the cell growth inhibition induced by resveratrol, the effect of the agent on the cell cycle progression of MCF-7 was tested. Tumor cells were exposed to graded concentrations of the drug ranging from 5 to $20 \mu \mathrm{g} / \mathrm{ml}$ for 24, 48 and $72 \mathrm{~h}$ and then analyzed for cell cycle distribution by flow cytometry. The results illustrated in Fig. 4 show that cells exposed to 10 or $20 \mu \mathrm{g} / \mathrm{ml}$ of resveratrol accumulate in S-phase with a concomitant depletion of G1-phase cells at $24 \mathrm{~h}$. At $48 \mathrm{~h}$, this effect was particularly evident at all of the tested concentrations. At $72 \mathrm{~h}$, no significant differences were observed. 24h

$48 h$

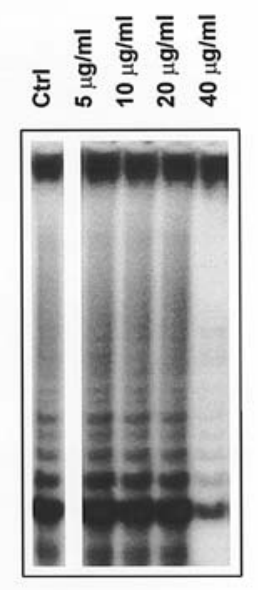

A

B

Figure 5. Effect of resveratrol on TLMA of MCF-7 cells. Cells were incubated with resveratrol at final concentration of 5, 10, 20 and $40 \mu \mathrm{g} / \mathrm{ml}$ (three wells for each treatment) or DMSO alone as control. Cells plated on day 0 were harvested 24 (A) and $48 \mathrm{~h}$ (B) after treatment and TLMA was evaluated by TRAP assay. Data relative to a representative experiment. Results expressing TLMA of total cultured cells, were calculated by densitometric analysis of the first 6 ladder bands, as described in Materials and methods. All data are expressed as percentage of variation with respect to untreated controls.

\section{吾 $\stackrel{\overline{\mathrm{g}}}{\mathrm{i}}$}

cytoplasm

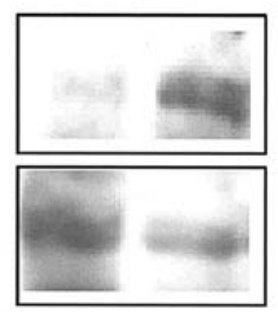

Figure 6. Effect of resveratrol on cell distribution of hTERT. Cells were incubated with resveratrol $(20 \mu \mathrm{g} / \mathrm{ml})$, and analysed by Western blot analysis on separated cytoplasmic and nuclear extracts after $36 \mathrm{~h}$ of incubation.

Effect of resveratrol on TLMA. MCF-7 cells were exposed in vitro to $5,10,20$ or $40 \mu \mathrm{g} / \mathrm{ml}$ of resveratrol and tested for TLMA 24 and $48 \mathrm{~h}$ after treatment. The results of the TRAP assay of a representative experiment that have been confirmed at least by three other independent experiments are illustrated in Fig. 5. A 24-h treatment of MCF-7 cells with resveratrol at $40 \mu \mathrm{g} / \mathrm{ml}$ caused $67 \%$ inhibition of TLMA with respect to the control (Fig. 5A). At lower concentrations (i.e. 5, 10, $20 \mu \mathrm{g} / \mathrm{ml}$ ), the enzyme activity was not affected. At $48 \mathrm{~h}$, the treatment of neoplastic cells with $5,10,20$ and $40 \mu \mathrm{g} / \mathrm{ml}$ of resveratrol was followed by a concentration-dependent reduction of TLMA with respect to that of controls (Fig. 5B). In particular, resveratrol treatment for $48 \mathrm{~h}$ with 5 and $10 \mu \mathrm{g} / \mathrm{ml}$ was followed by a marginal reduction of TLMA (13.9 and 19.3\%, respectively). On the other hand, $48 \mathrm{~h}$ after treatment with 
20 and $40 \mu \mathrm{g} / \mathrm{ml}$, the drug provoked a substantial decrease in TLMA (63.7 and $93 \%$ respectively).

Effect of resveratrol on intracellular distribution of hTERT. Several studies have shown that phosphorylation and nuclear localization of the catalytic subunit, hTERT, is required to maintain telomere elongation in different models (53-55). In the present study, we found that, in normal conditions in MCF-7 cells, hTERT is exclusively localized into the nuclear compartment (Fig. 6). Thirty-six hours of treatment with high concentrations (i.e. $20 \mu \mathrm{g} / \mathrm{ml}$ ) of resveratrol was able to reduce the amount of hTERT component in the nucleus, i.e. in the cell compartment where this subunit is required for telomere elongation. At the same time, the amount of hTERT in the cytoplasmic compartment appears to be up-regulated, suggesting that resveratrol is able to interfere with the machinery involved in the translocation of the subunit from the cytoplasm to the nucleus.

\section{Discussion}

The present study demonstrates that resveratrol treatment of the MCF-7 breast cancer cell line is able to reduce the number of viable cells, preventing exponential growth and inducing apoptosis and cell cycle perturbation. Moreover, this agent has been found to reduce TLMA in the same malignant cells. The biological effects of resveratrol on cell growth and apoptosis, supported by flow cytofluorimetric analysis and confocal fluorescence microscopy observations, appear to be concentration- and time-dependent. The measurement of cellular DNA content for the analysis of cell cycle distributions showed that cell growth inhibition was accompanied by a reduction of cells in G1, simultaneously with accumulation of cells in the S-phase of the cell cycle. Furthermore, we found that high concentrations of resveratrol were able to downregulate TLMA. This effect was accompanied by a reduction in hTERT protein in the nuclear compartment and concomitant increase of the molecule in the cytoplasm.

Results on antiproliferative effects of resveratrol appear to be in line with previous studies indicating that comparable concentrations of this polyphenol have a direct effect on human breast epithelial cells (30-36). The mechanism underlying the resveratrol-mediated inhibition of cell growth probably involves a disruption of cell cycle control, as shown by the significant accumulation of cells in the S-phase $(26,29,33,34)$, but still remains to be determined. The increase in S-phase could be a result of cellular arrest or a transition time delay through this phase. Alternatively, it could be due to the onset and execution of apoptosis in correspondence with G1 and $\mathrm{G} 2 / \mathrm{M}$ phases, providing a possible explanation for the antiproliferative effect of resveratrol.

The present study shows that high concentrations of resveratrol mediate the down-regulation of TLMA. Telomerase activity is usually absent in normal somatic cells, where telomeres are progressively shortened by cell division $(45,47)$. On the other hand, telomerase is specifically activated in most malignant tumors that acquire 'immortal' phenotype, since this enzyme complex is responsible for telomere length restoration after telomere erosion resulting from cell duplication (44-46).
Therefore, telomerase could be a novel and highly selective target for antitumor drug design. In fact, a number of reports have examined factors believed to inhibit TLMA (56). Disruption of telomere maintenance limits the cellular lifespan in human cancer cells, thus validating human telomerase as an important target for the development of anti-neoplastic therapies. Chemopreventive and anti-cancer agents able to inhibit TLMA push tumor cells into a crisis state leading to apoptosis (16,57-59).

The antitumor and antiproliferative activities of resveratrol probably rely on several mechanisms of action $(15,19,24,25$, $58,60)$. One of these, possibly shared by other polyphenols, might involve the disruption of signalling pathways and modulation of nuclear factors $(15,16,19,38,39)$. In particular, resveratrol could be directly or indirectly involved in the control of the cell cycle through cell-specific and concentrationdependent effects on cell-cycle regulators $(33,34,36)$. In our study, this polyphenol significantly inhibits, in a time- and concentration-related manner, cell growth by inducing apoptosis and possibly perturbing the cell cycle by restricting the progression of cells through the S-phase. These effects could be due to an indirect mechanism involving down-regulation of TLMA and interference with cancer-related cell signal transduction pathways, implicated in apoptosis and cell cycle control. This hypothesis is supported by a recent study of Del Bufalo et al (61) who suggested a possible role of hTERT in directly or indirectly controlling cell survival through the modulation of genes implicated in apoptosis. The suppression of telomerase function promotes apoptosis in several cells, assigning to hTERT a putative anti-apoptotic role, which is independent of its enzymatic and telomere-maintenance function. In particular, hTERT modulation directly interferes at an early stage of the intrinsic apoptotic pathway upstream of mitochondrial alterations (61).

In addition, the results of the present study point out that resveratrol is able to alter the cellular distribution of the catalytic subunit, hTERT. In particular, we observed that high concentrations of resveratrol reduced the levels of nuclear hTERT, while the cytoplasmic levels of the protein appeared to be limitedly up-regulated (Fig. 6). Several studies have shown that TLMA can be activated by posttranscriptional phosphorylation and nuclear translocation of the catalytic subunit hTERT $(49,55)$. Our results suggest the hypothesis that resveratrol reduces TLMA in MCF-7 cells by affecting hTERT transport from the cytoplasm to the nucleus, thus altering its intracellular distribution. Inhibition of hTERT translocation induces a down-regulation of intranuclear hTERT, that is crucial for cell survival. The redistribution of hTERT in intracellular compartments could in turn enhance the pro-apoptotic effect of resveratrol.

Resveratrol treatment of MCF-7 cells has been associated with reduced levels of phosphorylated Akt, an important positive regulator of cell survival $(16,60)$ and NF- $\mathrm{KB}$ $(15,38,58)$. TLMA is known to be regulated at a posttranscriptional level via phosphorylation by Akt kinase (62). Moreover, NF- $\mathrm{KB}$ plays a pivotal role in regulating telomerase by modulating hTERT nuclear translocation in different cell models $(54,63)$. Therefore, it can be suggested that the marked changes of cellular distribution of hTERT observed in our model, might be explained by the reduction of NF- $\mathrm{BB}$ and 
phosphorylated Akt previously reported in resveratrol-treated MCF-7 cells (39).

These mechanisms mainly act during the first $24 \mathrm{~h}$ of exposure to the compound, during the exponential growth phase of the cells. Since apoptosis provides an efficient mechanism to eliminate unwanted cells during carcinogenesis, the increased mortality seen after resveratrol treatment may be due to its ability to induce apoptotic cell death during neoplastic transformation (64) and hence this bioactive compound could be a candidate for cancer therapy.

The effects of resveratrol on hTERT and telomerase function point out that this agent possesses pronounced tumor suppressor activity in line with its chemopreventive properties. Based on the reported findings, resveratrol appears to be worthy of further investigation. This agent can be considered a promising chemoprotective, chemopreventive and chemotherapeutic compound, able to play a significant role in the control of human breast cancer. Further studies are in progress to elucidate the molecular mechanisms underlying the pharmacodynamic profile of resveratrol, especially those involving its influence on TLMA.

\section{Acknowledgements}

This study was supported in part by grants from 'Convenzione Provincia Autonoma di Trento (PAT) - Consiglio Nazionale delle Ricerche (CNR)' and in part by AIDS project \# 50F.17 (OF) of Istituto Superiore di Sanità, Rome (Italy).

\section{References}

1. Langcake P and Pryce RJ: The production of resveratrol by Vitis vinifera and other members of the Vitaceae as a response to infection or injury. Physiol Plant Pathol 9: 77-86, 1976.

2. Soleas GJ, Diamandis EP and Goldberg DM: Resveratrol: a molecule whose time has come? And gone? Clin Biochem 30: 91-113, 1997

3. Frémont L: Biological effects of resveratrol. Life Sci 66: 663-673, 2000.

4. Rimm EB, Klatsky A, Grobbee D and Stampfer MJ: Review of moderate alcohol consumption and reduced risk of coronary heart disease: is the effect due to beer, wine or spirits. BMJ 312 : 731-736, 1996

5. Gaziano JM, Buring JE, Breslow JL, Goldhaber SZ, Rosner B, van Denburgh M, Willet W and Hennekens $\mathrm{CH}$ : Moderate alcohol intake, increased levels of high-density lipoproteins and its subfractions and decreased risk of myocardial infarction. $\mathrm{N}$ Engl J Med 329: 1829-1834, 1993.

6. Renaud S and Delorgeril M: Wine, alcohol, platelets and the French paradox for coronary heart disease. Lancet 339: 1523-1526, 1992.

7. Constant J: Alcohol, ischemic heart disease, and the French paradox. Coron Artery Dis 8: 645-649, 1997.

8. Bradamante S, Barenghi L and Villa A: Cardiovascular protective effects of resveratrol. Cardiovasc Drug Rev 22: 169-188, 2004.

9. Hao HD and He LR: Mechanisms of cardiovascular protection by resveratrol. J Med Food 7: 290-298, 2004.

10. Pace-Asciak CR, Hahn S, Diamandis EP, Soleas G and Goldberg DM: The red wine phenolics trans-resveratrol and quercetin block human platelet aggregation and eicosanoid synthesis: implications for protection against coronary heart disease. Clin Chim Acta 235: 207-219, 1995.

11. Frankel EN, Waterhouse AL and Kinsella JE: Inhibition of human LDL oxidation by resveratrol. Lancet 341: 1103-1104, 1993.

12. Fauconneau B, Waffo-Teguo P, Huguet F, Barrier L, Decendit A and Merillon JM: Comparative study of radical scavenger and antioxidant properties of phenolic compounds from Vitis vinifera cell cultures using in vitro tests. Life Sci 61: 2103-2110, 1997.
13. Bertelli AA, Giovannini L, Giannessi D, Migliori M, Bernini W, Fregoni $\mathrm{M}$ and Bertelli A: Antiplatelet activity of synthetic and natural resveratrol in red wine. Int J Tissue React 17: 1-3, 1995.

14. Hsieh TC, Juan G, Darzynkiewicz Z and Wu JM: Resveratrol increases nitric oxide synthase, induces accumulation of p53 and p21 (WAF1/CIP1), and suppresses cultured bovine pulmonary artery endothelial cell proliferation by perturbing progression through S and G2. Cancer Res 59: 2596-2601, 1999.

15. Aggarwal BB, Bhardwaj A, Aggarwal RS, Seeram NP, Shishodia S and Takada Y: Role of resveratrol in prevention and therapy of cancer: preclinical and clinical studies. Anticancer Res 24: 2783-2840, 2004

16. Pozo-Guisado E, Lorenzo-Benayas MJ and FernandezSalguero PM: Resveratrol modulates the phosphoinositide 3kinase pathway through an estrogen receptor alpha-dependent mechanism: relevance in cell proliferation. Int J Cancer 109: 167-173, 2004.

17. Estrov Z, Shishodia S, Faderl S, Harris D, Van Q, Kantarjian HM, Talpaz M and Aggarwal BB: Resveratrol blocks interleukin1beta-induced activation of the nuclear transcription factor NF-kappaB, inhibits proliferation, causes S-phase arrest and induces apoptosis of acute myeloid leukemia cells. Blood 102: 987-995, 2003.

18. Manna SK, Mukhopadhyay A and Aggarwal BB: Resveratrol suppresses TNF-induced activation of nuclear transcription factors NF-kappa B, activator protein-1 and apoptosis: potential role of reactive oxygen intermediates and lipid peroxidation. J Immunol 164: 6509-6519, 2000.

19. Kundu JK and Surh YJ: Molecular basis of chemoprevention by resveratrol: NF-kappaB and AP-1 as potential targets. Mutat Res 555: 65-80, 2004

20. Jang M, Cai L, Udeani GO, Slowing KV, Thomas CF, Beecher CW, Fong HH, Farnsworth NR, Kinghorn AD, Mehta RG, Moon RC and Pezzuto JM: Cancer chemopreventive activity of resveratrol, a natural product derived from grapes. Science 275: 218-220, 1997.

21. Subbaramaiah K, Chung WJ, Michaluart P, Telang N, Tanabe T, Inoue H, Jang M, Pezzuto JM and Dannenberg AJ: Resveratrol inhibits cyclo-oxigenase-2 transcription and activity in phorbol ester-treated human mammary epithelial cells. J Biol Chem 273: 21875-21882, 1998 .

22. Martinez J and Moreno JJ: Effect of resveratrol, a natural polyphenolic compound, on reactive oxygen species and prostaglandin production. Biochem Pharmacol 59: 865-870, 2000.

23. Cal C, Garban H, Jazirehi A, Yeh C, Mizutani Y and Bonavida B: Resveratrol and cancer: chemoprevention, apoptosis and chemoimmunosensitizing activities. Curr Med Chem Anti-Cancer Agents 3: 77-93, 2003.

24. Aziz MH, Kumar R and Ahmad N: Cancer chemoprevention by resveratrol: in vitro and in vivo studies and the underlying mechanisms (review). Int J Oncol 23: 17-28, 2003.

25. Dong Z: Molecular mechanism of the chemopreventive effect of resveratrol. Mutat Res 523-524: 145-150, 2003.

26. Della Ragione F, Cucciolla V, Borriello A, Della Pietra V, Racioppi L, Soldati G, Manna C, Galletti P and Zappia V: Resveratrol arrests the cell division cycle at $\mathrm{S} / \mathrm{G} 2$ phase transition. Biochem Biophys Res Commun 250: 53-58, 1998.

27. Fuggetta MP, D'Atri S, Lanzilli G, Tricarico M, Cannavo E, Zambruno G, Falchetti R and Ravagnan G: In vitro antitumour activity of resveratrol in human melanoma cells sensitive or resistant to temozolomide. Melanoma Res 14: 189-196, 2004.

28. Hsieh TC and Wu JM: Differential effects on growth, cell cycle arrest and induction of apoptosis by resveratrol in human prostate cancer cell lines. Exp Cell Res 249: 109-115, 1999.

29. Hsieh TC, Burfeind P, Laud K, Backer JM, Traganos F, Darzynkiewicz Z and Wu JM: Cell cycle effects and control of gene expression by resveratrol in human breast carcinoma cell lines with different metastatic potential. Int J Oncol 15: 245-252, 1999.

30. Damianaki A, Bakogeorgou E, Kampa M, Notas G, Hatzoglou A, Panagiotou S, Gemetzi C, Kouroumalis E, Martin PM and Castanas E: Potent inhibitory action of red wine polyphenols on human breast cancer cells. J Cell Biochem 78: 429-441, 2000.

31. Mgbonyebi OP, Russo J and Russo IH: Antiproliferative effect of resveratrol on human breast epithelial cells. Int J Oncol 12: 865-869, 1998.

32. Lu R and Serrero G: Resveratrol, a natural product derived from grape, exhibits antiestrogenic activity and inhibits the growth of human breast cancer cells. J Cell Physiol 179: 297-304, 1999. 
33. Joe AK, Liu H, Suzui M, Vural ME, Xiao D and Weinstein IB: Resveratrol induces growth inhibition, S-phase arrest, apoptosis and changes in biomarker expression in several human cancer cell lines. Clin Cancer Res 8: 893-903, 2002

34. Pozo-Guisado E, Alvarez-Barrientos A, Mulero-Navarro S, Santiago-Josefat B and Fernandez-Salguero PM: The antiproliferative activity of resveratrol results in apoptosis in MCF-7 but not in MDA-MB-231 human breast cancer cells: cell-specific alteration of the cell cycle. Biochem Pharmacol 64: 1375-1386, 2002.

35. Basly JP, Marre-Fournier F, Le Bail JC, Habrioux G and Chulia AJ: Estrogenic/antiestrogenic and scavenging properties of (E)- and (Z)-resveratrol. Life Sci 66: 769-777, 2000.

36. Nakagawa H, Kiyozuka Y, Uemura Y, Senzaki H, Shikata N, Hioki K and Tsubura A: Resveratrol inhibits human breast cancer cell growth and may mitigate the effect of linoleic acid, a potent breast cancer cell stimulator. J Cancer Res Clin Oncol 127: 258-264, 2001.

37. Gehm BD, McAndrews JM, Chien PY and Jameson JL: Resveratrol, a polyphenolic compound found in grapes and wine, is an agonist for the estrogen receptor. Proc Natl Acad Sci USA 94: 14138-14143, 1997.

38. Pozo-Guisado E, Merino JM, Mulero-Navarro S, LorenzoBenayas MJ, Centeno F, Alvarez-Barrientos A and Salguero PM: Resveratrol-induced apoptosis in MCF-7 human breast cancer cells involves a caspase-independent mechanism with downregulation of Bcl-2 and NF-kappaB. Int J Cancer 115: 74-84, 2005.

39. Sarkar FH and Li Y: Cell signaling pathways altered by natural chemopreventive agents. Mutat Res 555: 53-64, 2004.

40. Morin GB: The human telomerase terminal transferase enzyme is a ribonucleoprotein that synthesizes TTAGGG repeats. Cell 59: $521-529,1989$.

41. Shay JW: Aging and cancer: are telomeres and telomerase the connection? Mol Med Today 1: 378-384, 1995.

42. Hahn WC, Stewart SA, Brooks MW, York SG, Eaton E, Kurachi A, Beijersbergen RL, Knoll JH, Meyerson M and Weinberg RA: Inhibition of telomerase limits the growth of human cancer cells. Nat Med 5: 1164-1170, 1999.

43. Zhang X, Mar V, Zhou W, Harrington L and Robinson MO: Telomere shortening and apoptosis in telomerase-inhibited human tumor cells. Genes Dev 13: 2388-2399, 1999.

44. Damm K, Hemmann U, Garin-Chesa P, Hauel N, Kauffmann I, Priepke H, Niestroj C, Daiber C, Enenkel B, Guilliard B, Lauritsch I, Muller E, Pascolo E, Sauter G, Pantic M, Martens UM, Wenz C, Lingner J, Kraut N, Rettig WJ and Schnapp A: A highly selective telomerase inhibitor limiting human cancer cell proliferation. EMBO J 20: 6958-6968, 2001.

45. Hahn WC and Meyerson M: Telomerase activation, cellular immortalization and cancer. Ann Med 33: 123-129, 2001.

46. Kim NW, Piatyszek MA, Prowse KR, Harley CB, West MD, Ho PL, Coviello GM, Wright WE, Weinrich SL and Shay JW: Specific association of human telomerase. Activity with immortal cells and cancer. Science 266: 2011-2015, 1994.

47. Rhyu MS: Telomeres, telomerase and immortality. J Natl Cancer Inst 87: 884-894, 1995.

48. Boldrini L, Faviana P, Gisfredi S, Zucconi Y, Di Quirico D, Donati V, Berti P, Spisni R, Galleri D, Materazzi G, Basolo F, Miccoli P, Pingitore R and Fontanini G: Evaluation of telomerase mRNA (hTERT) in colon cancer. Int J Oncol 21: 493-497, 2002.
49. Kimura A, Ohmichi M, Kawagoe J, Kyo S, Mabuchi S, Takahashi T, Ohshima C, Arimoto-Ishida E, Nishio Y, Inoue MM, Kurachi H, Tasaka K and Murata Y: Induction of hTERT expression and phosphorylation by estrogen via Akt cascade in human ovarian cancer cell lines. Oncogene 23: 4505-4515, 2004.

50. Nicoletti I, Migliorati G, Pagliacci MC, Grignani F and Riccardi C: A rapid and simple method for measuring thymocyte apoptosis by propidium iodide staining and flow cytometry. J Immunol Methods 139: 271-279, 1991.

51. Piatyszek MA, Kim NW, Weinrich SL, Hiyama K, Hiyama E, Wright WE and Shay JW: Detection of telomerase activity in human cells and tumors by a telomeric repeat amplification protocol (TRAP). Methods Cell Sci 17: 1-15, 1995.

52. Andrews NC and Faller DV: A rapid micropreparation technique for extraction of DNA-binding proteins from limiting numbers of mammalian cells. Nucleic Acids Res 19: 2499, 1991.

53. Swiggers SJ, Nibbeling HA, Zeilemaker A, Kuijpers MA, Mattern KA and Zijlmans JM: Telomerase activity level, but not hTERT mRNA and hTR level, regulates telomere length in telomerase-reconstituted primary fibroblasts. Exp Cell Res 297: 434-443, 2004.

54. Liu K, Hodes RJ and Weng NP: Cutting edge: telomerase activation in human $\mathrm{T}$ lymphocytes does not require increase in telomerase reverse transcriptase (hTERT) protein but is associated with hTERT phosphorylation and nuclear translocation. J Immunol 166: 4826-4830, 2001.

55. Smogorzewska A and De Lange T: Regulation of telomerase by telomeric proteins. Annu Rev Biochem 73: 177-208, 2004.

56. Rezler EM, Bearss DJ and Hurley LH: Telomere inhibition and telomere disruption as processes for drug targeting. Annu Rev Pharmacol Toxicol 43: 359-379, 2003

57. Yokoyama M, Noguchi M, Nakao Y, Pater A and Iwasaka T: The tea polyphenol, (-)-epigallocatechin gallate effects on growth, apoptosis and telomerase activity in cervical cell lines. Gynecol Oncol 92: 197-204, 2004.

58. Dorai T and Aggarwal BB: Role of chemopreventive agents in cancer therapy. Cancer Lett 215: 129-140, 2004.

59. Naasani I, Oh-Hashi F, Oh-Hara T, Feng WY, Johnston J, Chan K and Tsuruo T: Blocking telomerase by dietary polyphenols is a major mechanism for limiting the growth of human cancer cells in vitro and in vivo. Cancer Res 63: 824-830, 2003.

60. Brownson DM, Azios NG, Fuqua BK, Dharmawardhane SF and Mabry TJ: Flavonoid effects relevant to cancer. J Nutr 132 (Suppl 11): S3482-S3489, 2002.

61. Del Bufalo D, Rizzo A, Trisciuoglio D, Cardinali G, Torrisi MR, Zangemeister-Wittke U, Zupi G and Biroccio A: Involvement of hTERT in apoptosis induced by interference with Bcl-2 expression and function. Cell Death Differ 12: 1429-1438, 2005.

62. Kang SS, Kwon T, Kwon DY and Do SI: Akt protein kinase enhances human telomerase activity through phosphorylation of telomerase reverse transcriptase subunit. J Biol Chem 274: 13085-13090, 1999

63. Akiyama M, Hideshima T, Hayashi T, Tai YT, Mitsiades CS, Mitsiades N, Chauhan D, Richardson P, Munshi NC and Anderson KC: Nuclear factor-kappaB p65 mediates tumor necrosis factor alpha-induced nuclear translocation of telomerase reverse transcriptase protein. Cancer Res 63: 18-21, 2003.

64. Bode AM and Dong Z: Targeting signal transduction pathways by chemopreventive agents. Mutat Res 555: 33-51, 2004. 